\title{
IMPACT OF THE GYNECOLOGICAL INTERVENTIONS ON THE PATIENTS' QUALITY OF LIFE
}

KEY WORDS: gynecological intervention, quality of life, selfassessment.

\section{Ekaterine Isakidi Otar Vasadze*}

$\mathrm{DM}, \mathrm{PHD}(\mathbf{s})$

Goal: The final goal of the medical intervention is to improve the patient's quality of life. This descriptive study evaluates the impact of the gynecological interventions on the patient's quality of life. As well as it evaluates the quality of life based on objective and subjective criteria, the identification and determination of which is very important for the accurate determination of the patient's quality of life before and after the medical intervention.

Methods: The questionnaire developed by the World Health Organization (WHOQOL-BREF) consisting of 26 questions and evaluating 4 dimensions of quality of life: physical health, mental state, social relations and the environment, was used in this study. It should be noted that the questionnaire was translated into Georgian within the frame of this study. The Data Statistics Program was implemented through SPSS 24. TheWilcoxon signed-rank test was used.

Results: The study was conducted in 2020 in three medical institutions in 2 stages, before and after the gynecological interventions. 225 patients were interviewed in the first stage and 188 patients in the second stage. $27.1 \%(61)$ of the study participants were patients aged 18-35, $51.6 \%$ (116) were aged 35-54, and $21.3 \%$ (48) were patients aged 55 and older.

\section{INTRODUCTION:}

In addition to the sociologists other leading fields, such as economics, social psychology, etc. also started studying the human's quality of life at the scientific level (Sampogna,2013).

The philosophical concept of the quality of life in the developed countries of the world is used as an important tool for assessment of the public policy and social work, as a mean of influencing the effectiveness of the management. (Асранасьева E, 2010).

The development of the life concept related to the health care expands the interpretation and understanding of the term, which includes the person's social, physical and mental factors (Альбицкий, 2002).

An important factor is the assessment of the partnership between the doctor and the patient, where both sides openly provide information about the problematic fields (Шевченко 2000, Сенкевич 2000)

Most of the researchers underline the importance of the assessment of the functional ability (Решетников, 2003). The perception and assessment of the functional skills affects both the mental state and social activity, that is reflected on the mental and physical functions (Torrance, 2000).

The patient's ability to adapt to the existence of the disease is considered as an indicator of the quality of life. In recent years the research activities have significantly increased all around the world, which has increased the effectiveness of the reforms in the field of the healthcare in the various states around the world (Балабуха, 2010).

The results of the study of the quality of life show that the nature, duration and intensity of the pain are mainly due to unfavorable life situations, social and economic problems, and do not depend solely on the volume of the damage caused (Guyatt.2002).

Another area for the successful application of the assessment of the quality of life criteria is the economic feasibility of treatment methods, taking into account indicators such as "price quality", "cost efficiency" and other pharmacoeconomic criteria (Воробьев, 2000).

The quality of life is defined as the individual ability to act in the society (labor, social, activity, family life) and as a complex of physical, emotional, mental and intellectual characteristics of the person (Хетагурова, 2003).

Therefore, for the assessment of the quality of life such a tool should be used, which includes various aspects of the quality of life associated with the health. It is important that such tools can be used for the people of the different age, profession, and in case of the different diseases. At the same time, it should be a simple, concise, understandable document, through which it is possible to quantify the parameters studied (Деларю, 2005; Евдокимов 2008).

\section{Statistical analysis}

For describing the results during the statistical analysis of the data Frequency Analysis Method and cross-tabulation were used, and for comparing the results "before" and "after" the Wilcoxon signed-rank test (matched pairs) was chosen, which provides the opportunity to compare statistical reliability/significance of the changes in the "before" and "after" design.

$23.6 \%$ (53) of the respondents underwent the hysterectomy with appendages or hysterectomy without appendages, $48 \%$ (108) of the respondents underwent the myomectomy or cystectomy, and $28.6 \%$ (64) of the respondents underwent hysteroscopy and other surgical interventions.

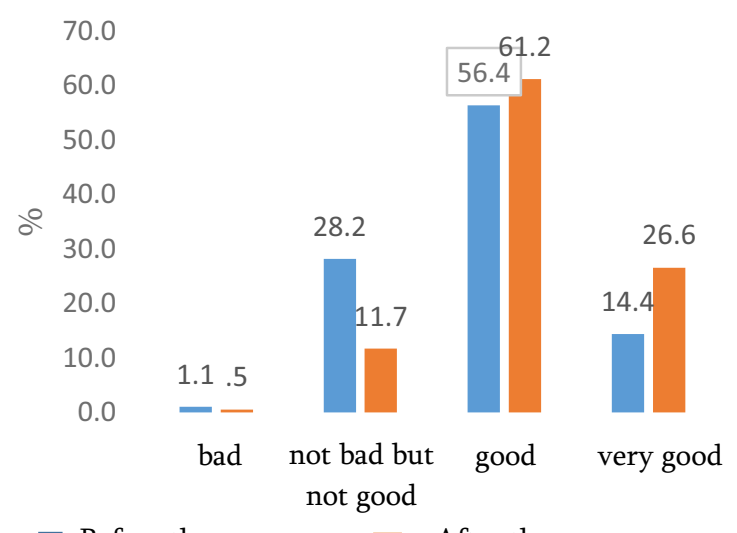

Before the surgery $\quad$ After the surgery

Diagram 1. Comparison of the assessments of the quality of life before and after the surgery 
$41.5 \%$ (78) of the patients assessed their quality of life with the better score, and $17 \%$ (32) of the patients assessed their quality of life with the less score after the surgery. Wilcoxon signed-rank test was used for the assessment of the reliability of the change that occurred after the operation. The statistical analysis showed that the change that occurred in the improvement of the assessment is statistically reliable $(\mathrm{P}<0.001)$.

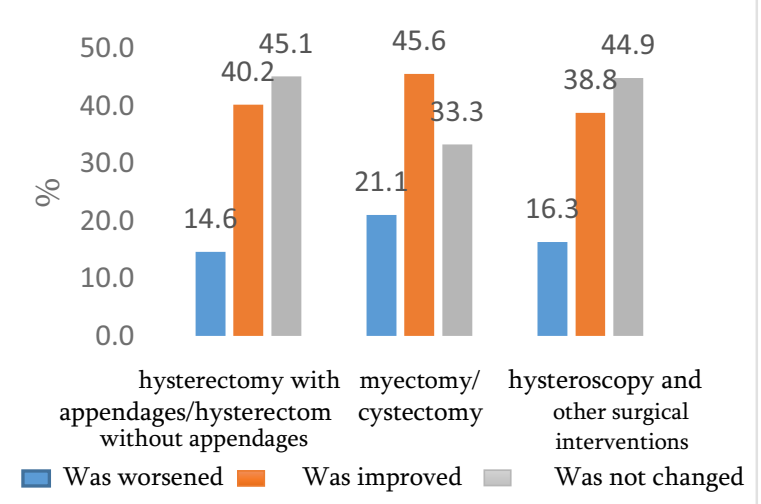

Diagram 2. Change of the assessment of the quality of life after the surgery due to the types of the surgical interventions, Wilcoxon signed-rank test

The importance of the change in satisfaction with the health state before and after the surgery was checked through the Wilcoxon signed-rank test. "Before" and "after" pair comparisons showed that satisfaction with health state was worsened in $16.49 \%$ (31) of the patients, was improved in $48.4 \%$ (91) of the patients, and did not change in $35.11 \%(66)$ of the patients. Overall positive change is statistically reliable $(\mathrm{P}<0.001)$.

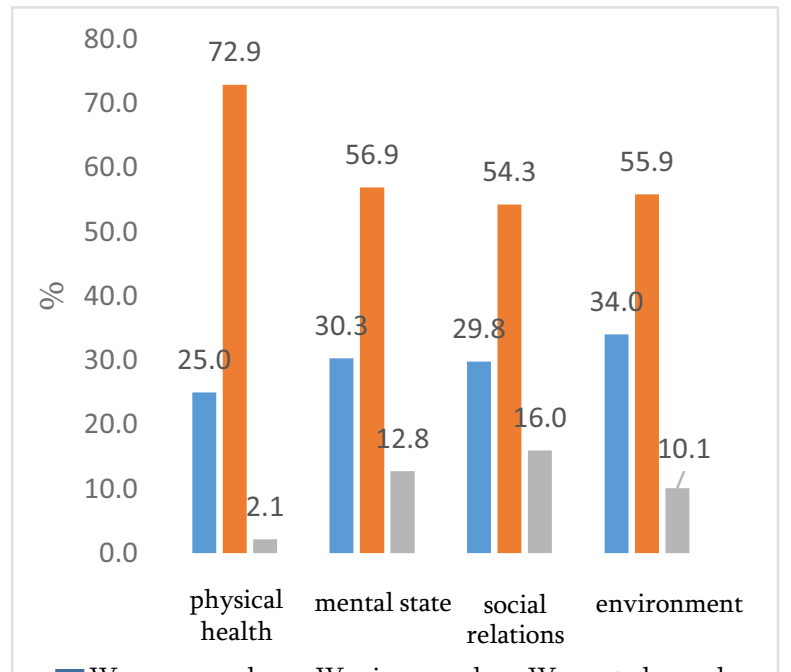

$\square$ Was worsened $\square$ Was improved $\square$ Was not changed

\section{Diagram 3. Assessment of the changes occurred after the surgery due to 4 area of the quality of life}

Wilcoxon signed-rank test was used to assess the statistical significance of the changes that occurred after the surgery, and the analysis showed that changes occurring in all four areas are statistically significant, and in all four cases $\mathrm{P}<0.001$.

\section{Conclusion and Recommendations}

1. This study has confirmed that the gynecological interventions improve the patients' quality of life, while this improvement was found an important for most categories of the demographic variables studied.

2. The indicators of the areas of the "mental state", "social relations" and "adapting to the environment" have improved in two groups: in the group of the patients undergoing the total hysterectomy with appendages/ without appendages and in the group of the patients undergoing the myomectomy/cystectomy.

3. The introduction of such type of the approach, when clinical methods will be integrated to the assessment of the dimensions of the quality of life in the health care institutions will increase the quality of the medical care and finally will help to improve the health state of the population.

\section{REFERENCES}

[1]. Sampogna F. (2013). Life course impairment and quality of life over time. Current problems in dermatology, 44, 47-51. https://doi.org/10.1159/ 000350781

[2]. Афанасьева Е.В., Оценка качества жизни, связанного со здоровьем. Качественная Клиническая Практика. 2010;(1):36-38. https://www.clinvest. $\mathrm{ru} /$ jour/article/view/126

[3]. Альбицкий, В. Ю., (2002). К вопросу изучения воспроизводства здоровья населения. Москва. Вып. 4,ч. 1-С. 13-26.

[4]. Шевченко, Ю.Л., (2000). Концепция исследования качества жизни в здравоохранении. Медицинские новости. 001. - № 4.- С. 51-52

5]. Сенкевич, Н.Ю., (2000). Качество жизни в медицине. Т. 3.-С. 36-41

[6]. Решетников, А.В., (2000). Эволюция и проблемы современной социологии медицины Экономика здравоохранения. № 5/6. -С. 45

[7]. Torrance G.W. (1987). Utility approach to measuring health-related quality of life. Journal of chronic diseases, 40(6), 593-603. https://doi.org/10.1016/ 0021-9681(87)90019-1

[8]. Балабуха, О.С., (2010). Качество жизни как основа программ реабилитации онкологических больных. Междунар. мед. журн. № 4.-С. 1113.http://dspace.nbuv.gov.ua/handle/123456789/30595

[9]. Guyatt, G. H., Kirshner, B., \& Jaeschke, R. (1992). Measuring health status: what are the necessary measurement properties? Journal of clinical epidemiology, 45 (12), 1341-1345. https://www.jclinepi.com/article/0895-4356(92)90194$\mathrm{R} / \mathrm{pdf}$

[10]. Воробьев, П.А. (2000). Экономическая оценка эффективности лекарственной терапии, Москва. 80 с

[11]. Хетагурова, А.К., (2003). Паллиативная помощь, медико-социальные, организационные и этические принципы. с 123.

[12]. Деларю, В.В., (2005). Клиническая психология и медицинская психология: соотнесение понятий. № 3/4. - С. 45-47.

[13]. Евдокимов, В.И., (2008). Научно-методологические проблемы оценки качества жизни, Вестник психиатрии. №27. - С. 102-131.

[14]. Тодров, 1980; The whoqol Group, 2001) 